\title{
Studying-up those who fell down: elite transformation in
}

\section{Nepal.}

\author{
Stefanie Lotter (University of Heidelberg)
}

This article discusses the methodological challenges of studying elites, and argues that both the negotiation of access and the position of the researcher in relation to the studied elite group are vital to the research outcome. Unlike previous studies that took the stance of associating with the elites, this article favours a perspective 'from below' borrowing conceptually from 'subaltern studies' to reveal the working of gatekeepers and the study of imposed hierarchy as an inherent part of the representation of an elite culture. Studying the Rana, an elite clan past its prime, this study shows that an approach beginning with the declined periphery and proceeding to the power centre presents an extensive view on the working of elites.

The Rana effectively ruled Nepal for over 100 years until they lost power following a revolution in 1951. While they held all key posts in politics as well as in the civil and military administration before the revolution, their influence considerably declined after their fall from power. Despite maintaining strong personal links with the royal family, the Shah, and a high profile in many of Nepal's leading companies, few political and military leaders come from the Rana clan any more. Many of today's Rana survive by living off profits from their property, failing to maintain the living standards of previous generations of ruling Rana.

Using the practical definition of elites as: 'those who get the most of what there is to get, in any institutionalised sector of society...' (H. D. Lasswell cited in Marvick 1996: 238), it is evident that the Rana have transformed from a entire clan that previously qualified as elites, to a clan from which a considerable number of current elites still originate. In this respect my study of contemporary Rana has included "effective elites"1 (those who would be recognized as such in their area of expertise on an international level), as well as Rana who would qualify as middle class by their living standard if they were living in western Europe and not in Nepal.

Studying a declining elite clan rather than a defined segment of a particular elite (for example high ranking politicians or business consultants), my sample provided me the possibility to observe 'effective elites' in less formal occasions such as family gatherings where I accompanied their 'accessible' relatives. This situation allowed me to study interactions between influential and less influential Rana in a field that Tanya Luhrmann (1996) describes as predestined for 'appointment anthropology'. Luhrmann acknowledges the limitation of defined interview situations where the researcher has

\footnotetext{
${ }^{1}$ Along the lines of Stephen Nugent (2002: 72) one distinguishes between 'accessible' and 'effective' elites. Anthropologists may be able to gain access to the former and establish trust while the latter group is not as easily approached and has no structural need to consent to being studied.
} 
usually little scope for negotiation and is often confronted with the participants' highly choreographed self-representations. Beginning with the more accessible periphery of the Rana clan and working inward towards the exclusive and powerful centre provided me with glimpses of self-representation that was framed by family interaction rather than set in formal interviews. To illustrate the unusual research situation I had with elite participants, I remember well my astonishment when a certain Mr Rana ${ }^{2}$ had given me a time slot for an interview which was to be shared with a local newspaper journalist so that, as Mr. Rana explained, he would not have to repeat himself. In a research relationship with elites, participants need not to be given a voice in a project of empowerment. Elite participants can speak and write for themselves and as Herzfeld suggests the more important question in this environment is: 'How do we gain sufficient intimacy to be able to say anything about these people that they would not say for themselves?' (2000: 230). I argue that there are two directions leading out of the dilemma of elite studies. First, as anthropologists we need to find ways to avoid formalized interview situations, which is best achieved by gaining access to other interactions with the elite. Secondly, we need to acknowledge the potential of choreographed self-representation as a specific discursive form which can serve as a valuable alternative to the limited options of participant observation in elite settings.

Beginning with the second direction, I was surprised to find that elites are not only experienced in giving interviews but furthermore often perceive it as their duty to inform the public of their area of expertise and their public image. Public selfrepresentation is widespread and elaborate amongst the Rana and it is well known that they give countless press statements and interviews. Furthermore Daman S.J.B. Rana (1978), Jagadish Rana (1995), Padma Rana (1909), Pramode S.J.B. Rana (1978, 1995 and 2000) and Purushottam S.J.B. Rana $(1998,2055 \text { B.S })^{3}$ have written about the Rana in historical accounts. There are also several historical novels and fictionalized accounts of the Rana aristocracy published notably by Diamond Rana (1981 and 1984) who has been acknowledged as the father of Nepali historical fiction but also by Greta Rana (1977 and 1994) and Deepak Rana (pseudonym Ranabhumi). Recently a coffee table book on the Rana aristocracy was written by Pashupati, Prabhakar and Gautam SJB Rana (2002) and a large Rana genealogy was commissioned by the families' religious institution, the Pancayan (1999).

Spivak (1988a, 1988b) who writes about subaltern groups rather than elites, distinguishes between two modes of representation: Vertretung (proxy) and Darstellung (portrait). This distinction can help us to locate the literary work of the Rana on the Rana. Vertretung, understood in the sense of political representation, is 'speaking for' or in the interests of another person or group; while Darstellung is understood as 'placing there', or portraying. Subaltern groups, unlike elites, do not fully control the representation of their community; rather they rely widely on proxy representation provided by political activists and sometimes anthropologists who may represent their otherwise unheard voices. Dominant groups on the other hand, are not in need of such Vertretung (proxy) as they create numerous self-representations in a

\footnotetext{
${ }^{2} \mathrm{Mr}$ and Mrs Rana stand for anonymous participants in my study. Participants named with their full first names are not anonymous.

${ }^{3}$ B.S. is short for bikram sambat: the Nepali calendar which starts 57 years earlier than ours.
} 
kind of distanced self-Darstellung (portrait). In terms of Herzfeld's question, Spivak might suggest that the elite's capacity to 'speak for' themselves makes anthropological studies that produce Vertretung representations needless. There is no scope to write about elites as if there would be a need to represent their otherwise unheard voices. Studying elites, however, by studying the Darstellung of elites as conscious presentations of the self is a challenging undertaking and as indicated above in the case of the Rana - can be based on a well sorted corpus of material.

In addition to the above mentioned literary productions authored by Rana, recently several staged productions of the Rana theme have been produced. Biju S.J.B Rana for example, had just written 27 episodes for a half hour TV serial on his ancestor, the first Rana Prime Minister Jung Bahadur Rana, and was in the middle of selecting his actors when we last spoke. The description of how he chose to become an actor shows the ability of Darstellung, which is preserved even when the inherited membership to the effective elite has already been lost. Biju S.J.B. Rana used his knowledge of the Rana court to write about historical Rana. He also preserved his natural aristocratic habitus ${ }^{4}$ in order to perform on stage in the roles of the King of Nepal and amongst others Richard III, even though he had otherwise consciously unlearned his own courtly past in order to adapt to living a commoner's life. Unlike others, for him, acting naturally in the role of a ruler is not particularly difficult.

B. Rana It is like learning abc. That would not allow you to write poems. It's got to come from within and the theatre I suddenly found, well I had this natural feeling for being based in the public and speaking words or hmm-and yet, I'm no politician! So, what else could I be? But, an actor?

Concluding that he wanted to be based in the public sphere, Biju Rana decided to embark on a career in the performing arts. This choice provided him not only with an audience but with the possibility to express his increasingly conscious bodily memory (i.e. his former natural habitus) as a conscious Darstellung (portrait) of the Rana on stage. Without venturing further into a discussion on the probability of a conscious habitus, I will only state here that many Rana opted to represent their clan in public even when they were no longer in financially sound circumstances. Evidently this provided me with an interesting field of self representation and self reflection.

The contribution 'subaltern studies' provides for elite studies is however twofold: the highlighted emphasis on self-representation in the sense of Darstellung and the insistence on the 'from below' perspective even where other perspectives may be available. The 'from below' perspective although primarily concerned with subaltern resistance, does not exclude the writing of histories of so called 'great men' as Shahid Amin (1988) demonstrated. In South Asia 'subaltern studies' contrast with an earlier generation of researchers such as Louis Dumont (1966) who associated with elites thereby helping to construct the writing of South Asian history 'from above'. The later studies have been largely based on privileged access granted by local elites to western middle class researchers. The study of elites can however free itself from its historical traits of studying 'from above' and can now experiment with new approaches as discussed. For both the study of South Asia and the study of elites, this

\footnotetext{
${ }^{4}$ For Bourdieu, habitus is 'embodied history, internalised as a second nature and so forgotten as history is, the active presence of the whole past of which it is the product' (1990: 56).
} 
perspective frees the researcher from being associated with the colonial projects of earlier generations.

Peter Frankenberg (2002: 251) explains that when the comparison of class is based on consumption, many elites in rural Africa cannot compete with middle class western anthropologists. Such elites therefore need not be studied with a study-up approach. Hence they are 'accessible elites' rather than 'effective elites' with respect to western middle class researchers. Many of the recently published elite studies are the work of middle class anthropologists working with accessible elites (Harvey 2002, Eade 2002, Evers 2002 and Sobral 2000) rather then effective elites where the researcher must acknowledge his/her powerless position. Beyond the example of the western middle class anthropologist studying local African elites, accessibility in any elite setting is dependant not only on the exclusivity of the elite to be studied but also on the status of the individual researcher. This is easily demonstrated with the elite of this study, the Rana in Nepal. Susanne von der Heide (1997) a German anthropologist, produced a coffee table book about the Rana. While in Kathmandu, von der Heide rented a smaller size Rana palace to live in and her social circle included diplomats and local elites. Another German aristocrat, Kerrin Gräfin Schwerin (1993) wrote an article about the bad taste in Rana architecture and Adrian Sever, former ambassador of Australia to Kathmandu, published the largest historical compendium on the Rana (1993). Finally Julia Thompson (1997), the wife of an American diplomat in Kathmandu wrote her $\mathrm{PhD}$ thesis on the anthropology of beauty salons, including two larger sections on Rana women. Thompson reflected on her own social position in the field: 'My identity in Kathmandu as a young white American researcher married to an American diplomat helped me to straddle the social groups of poor student and privileged housewife' (Thompson 1997: 80). It is not surprising that Thompson, who had recently made the transition from a research student to the spouse of member of the diplomatic corps, is the only one of these writers who reflects upon her research position. Studying the Rana as a researcher who has access to the social field of elites, does not confront the researcher with the considerable problems of access and trust that are so widely discussed in elite-studies (see Nader 1969, Herz \& Imber 1993, Gusterson 1997 and Hunter 1993). Studying elites by affiliation risks overlooking the enforcement of institutionalized exclusivity and the overall choreography of presented images.

In contrast to the above mentioned studies, my own work on the Rana has to a large degree been a study of an 'effective elite' that rather than being studied by affiliation was approached from below. From this position I have been able to study 'gatekeepers' and other means by which the elites secure their privacy. Such a perspective is relatively new to the field of elite studies even though the term 'studying-up', which strongly suggests to work from below, dates back to Nader (1969). Until now, elite studies which concerned 'effective elites' relied mostly on secondary data drawn from media and historical sources (Eade 2002, Lima 2000 and Marcus 2000). Previous studies have brought anthropology into close proximity with other social sciences and investigative journalism; for example some anthropologists, such as Dan Rose (1990: 11), have worked undercover. Regardless of an ethical dismissal of this approach (following Gusterson 1997), undercover research with the Rana would have been difficult also in practical terms. I neither have the means or education to display myself convincingly as a member of the elite, nor could I think of a decent role which I could have adopted. The age of house teachers and foreign 
nannies has passed even in the most lavish Rana households. Thus I neither disguised myself nor hid my intentions when approaching possible participants of my study. Working from the periphery of the clan to the centre (i.e. from the more approachable end towards the more exclusive and powerful centre), I rejected the use of name dropping or association as a means of gaining access.

I first became acquainted with several elderly Rana who lived in tiny places all the while still preserving a style of nobility that was sometimes out of place in their mismatched surroundings. During my discussions with these elderly Rana, I not only listened to family histories that included financial decline and a focus on the domestic life of elites past their prime, but I was sometimes also invited to join my participants in the social space of their rich and powerful relatives. My experiences included appearing once at a wedding party with Rana relatives in a taxi which was abandoned outside the gates in order to avoid any indication of their financial decline (i.e not owning a car anymore). However with this point of entry alongside the less powerful, I still did not have unrestricted access to the social sphere of the 'effective' elites amongst the Rana clan. I learned through the association with 'accessible' Rana that even at family events, gatekeepers were in place to secure that 'effective' elites would have their privacy. To ensure this employees, also members of the Rana family, would oversee the segregation of guests including less 'effective' members of the Rana elite. These gatekeepers politely restrict the movements of participants whenever they try to leave their defined social space. On occasions with mixed audiences the Royal family would sometimes be present, seated elsewhere in the house, and all I would witness would be the security personal carrying ammunition to and from the garden, or the influential members of the Rana clan disappearing into the house while others, including me, were urged to the buffet in the garden. Without the conspiracy of 'effective' elites, access to the secluded sphere of powerful people is impossible. It is however vital to a study of elites to acknowledge this and to test ones limits and the limits of those one decided to associate with. Beyond these limits little can be done to secure the anthropologist further access. At best the anthropologist is helped to gain further access by the subversive acts of members of the 'effective' elites who then prefer to remains invisible. On securing an entrance, apparently without any help, politeness inhibits one from being asked to leave.

Despite my experiences of hierarchical seclusion at these large social events, I found that the difficulty of getting in touch with 'effective elites' did not always increase linearly with seniority and status. To my surprise several very high ranking Rana were rather approachable when I (detached from their 'poor' relatives) approached them as a research student at their workplace. Some even responded surprisingly quickly and were willing to give me time for an interview. For the duration of a two hour interview the illusion of equality or even friendly proximity was easily established by my high-end participants. Not unlike some anthropologists in other settings, elite participants in the study-up approach may abstain from using their powerful position, knowing that a dialogue that appears to be set between equals will win them sympathy. Working with elites meant working with professionals who are experienced with journalists, are aware of the danger of appearing arrogant and unapproachable and have decided to be or at least appear to be helpful and friendly. Appearance is conscious and trained from an early age in the elites, as Sreejana Rana put it: 'the last thing your parents want is you being snobbish'. 
The line between true recognition and the condescending attitude of the elite is hard for anyone to distinguish, including the researcher of elites. For example in her study of the wives of industrial elites in Germany, Böhnisch experiences a kind of charitable attitude from her informants that she calls 'motherly'. One of the interviewed women considers helping Böhnisch (1999: 66) after her $\mathrm{PhD}$ to find a job. Böhnisch interprets this offer as her informant's recognition of the power of knowledge and as her ability to see the $\mathrm{PhD}$ student as a future prestigious job holder among the elite. For Böhnisch, the one sided condescending offer to help does not mirror a power imbalance as I would have interpreted the situation. The failure to recognize the researcher's inferior position in relation to the studied elite leads to a false perception of equality in Böhnisch's case. Pierre Bourdieu (2001: 162) with whom I agree, points to the importance of analysing the social space in which social differentiation takes place. Böhnisch (1999: 44-5) meets her informants for a period of two to three hours in one to one respondent-oriented open interviews. She does not experience her interview partner in a larger group where she could have seen strategies of distinction or demarcation directed towards her. Böhnisch therefore has to rely on the spoken word in an artificial situation and as a result, is unable to analyse her own position. Members of elites may pretend to be on the same level as the anthropologist during the course of the interview, since they know that the chances of meeting the researcher again in their own social circle are small. During two hourlong interviews with top Rana elites, I was allowed to use their first name indicating their efforts to establish familiarity with me. This was in sharp contrast to my experiences at family events where the same individual made clear efforts to avoid me. The comfortable interview situation, where one sinks into a large sofa, a glass of wine in hand and sandwiches decorated on a silver platter to one side, may be an unusual working atmosphere for an anthropologist and one should not be deceived by what appears to be acceptance and familiarity. The gatekeepers of the elites are still present and the anthropologist is expected to leave after the two hour-long interview is finished and should have the decency not to return. Because I was studying a declining clan and was working and socialising with less influential relatives, I was able occasionally to see 'effective elites' in their proper social space. Being able to discuss events with the less influential relatives and experiencing with them how some elites avoided us was part of studying-up outside artificial interview situations.

I suppose I must have looked quite ridiculous at times being blanked, having backs turned on me, and left standing on my own while I was in the middle of a sentence. However I was working on elites and their decline and being ridiculous is certainly an experience I shared with many elites past their prime. Bourdieu has termed the inappropriateness that results from hysteresis $(1982: 238,496)$ in situations of downward social mobility, the 'Don Quixote' (1982: 188) effect. Some participants in my study and I myself, displayed features of 'Don Quixote', albeit different ones: they 'the knights' and myself 'up against the giants'. In summary, working with 'effective elites' is a challenging task due to the difficulties of access, the limitation of fieldwork to short term interviews and the choreographed self-representation of elites. Based on my experiences whilst studying the Rana, I suggest analysing the elites' self-representation as a specific literary form. In order to overcome time constraints and the artificial interview situations within spheres usually studied with the methods of 'appointment anthropology', I suggest to participate in further events with mixed audiences so that gatekeepers can be observed. Understanding the means of exclusion 
so intrinsic to the functioning of elites is one step closer to an understanding of the working of the elites.

\section{Bibliography}

Amin, S. 1988. Gandhi as Mahatma: Gorakhpur District, Eastern UP, 1921-2. In Selected subaltern studies (eds) R. Guha \& G.C. Spivak. Oxford: Oxford University Press.

Bourdieu, P. 1982 (franz. original 1979). Die feinen Unterschiede. Frankfurt a. M.: Suhrkamp.

Bourdieu, P. 1990. The logic of practice. Cambridge: Polity Press.

Bourdieu, P. 2001. Wie die Kultur zum Bauern kommt. Schriften zur Politik und Kultur 4. Hamburg: VSA-Verlag.

Böhnisch, T. 1999. Gattinnen: Die Frauen der Elite. Kritische Theorie und Kulturforschung Bd. 2 Zugleich Frankfurt/Main Dissertation 1999. Münster: Westfählisches Dampfboot.

de Lima, A. P. 2000. 'How did I become a leader in my family firm?' assets for succession in contemporary Lisbon financial elites. In Elites: choice leadership and succession (eds) J. de Pina-Cabral \& A.P. de Lima. Oxford: Berg.

Dumont, L. (1966) Homo hierarchicus: the caste system and its implications. Chicago and London: University of Chicago Press.

Eade, J. 2002. How far can you go? English Catholic elites and the erosion of ethnic boundaries. In Elite cultures: anthropological perspectives (eds) C. Shore \& S. Nugent. ASA Monographs v.38. London: Routledge.

Evers, S.J.T.M. 2002. The construction of elite status in the extreme Southern Highlands of Madagascar. In Elite cultures: anthropological perspectives (eds) C. Shore \& S. Nugent. ASA Monographs v.38. London: Routledge.

Frankenberg, P. 2002. Anthropologists: lions and/or foxes. An afterword. In Elite cultures: anthropological perspectives (eds) C. Shore \& S. Nugent. ASA Monographs v.38. London: Routledge.

Gusterson, H. 1997. Studying up revisited. Political and Legal Anthropology Review 20: $114-19$.

Harvey, P. 2002. Elites on the margins: mestizo traders in the southern Peruvian Andes. In Elite cultures: anthropological perspectives (eds) C. Shore \& S. Nugent. ASA Monographs v.38. London: Routledge.

Herz, R. \& J.B. Imber. 1993. Fieldwork in elite settings. Journal of Contemporary Ethnography 22: (1): 3-6.

Herzfeld, M. 2000. Uncanny success: some closing remarks. In Elites: choice leadership and succession (eds) J. de Pina-Cabral \& A.P. de Lima. Oxford: Berg.

Hunter, A. 1993. Local knowledge and local power: notes on the ethnography of local community elites. Journal of Contemporary Ethnography 22: (1) 36-58.

Luhrmann, T. 1996. The good Parsi: the fate of a colonial elite in a postcolonial society. Cambridge, Massachusetts: Harvard University Press. 
Marcus, G.E. 2000. The deep legacies of dynastic subjectivity: the resonances of a famous family identity in private and public space. In Elites: choice leadership and succession (eds) J. de Pina-Cabral \& A.P. de Lima. Oxford: Berg.

Marvick, D. 1996. Elites. In The social science encyclopaedia (eds) A. Kuper \& J. Kuper. London: Routledge.

Nader, L. 1969. Up the anthropologist-perspectives gained from studying up. In Reinventing anthropology (ed) D. Hymes. New York: Pantheon Books.

Nugent, S. 2002. Gente boa: elites in and of Amazonia. In Elite cultures: anthropological perspectives (eds) C. Shore \& S. Nugent. ASA Monographs v.38. London: Routledge.

Pāñcāyan Temple 1999. Kũvar Rānājiharuko buhat vaṃśāvalī. Kathmandu: Pāñcāyan publ.

Rana, Diamond S. 1981. Satparyas. Kathmandu: Balika Rana.

Rana, Diamond S. 1984. Wake of the white tiger. (English translation of Seto Bagh, translation by Greta Rana). Kathmandu: Balika Rana.

Rana, Daman S.J.B. 1978. Rana rule and misrule. Delhi.

Rana, Greta 1977. Distant hills. Kathmandu, Nepal: Sharda Prakashan Griha.

Rana, Greta 1994. Guests in this country: a third world fantasy. Delhi: Book Faith India.

Rana, Jagadish 1995. Nepal: a concise history of the cultural scenario of the Himalayan kingdom: South Asia Books.

Rana, Padma J.B. 1909. Life of Maharaja Sir Jung Bahadur of Nepal. Kathmandu: Ratna Pustak Bhandar

Rana, Pashupati S.J.B., Rana, Prabhakar S.J.B., \& Gautam S.J.B Rana. 2002. The Ranas of Nepal. Geneva: Naef. Kister S.S. Editeur.

Rana, Pramode S. 1978. Rana Nepal: an insider's view. Kathmandu: Rama Rana.

Rana, Pramode S. 1995. Rana intrigues. Kathmandu: Rama Rana.

Rana, Pramode S. 2000. A chronicle of Rana rule. Kathmandu: Rama Rana.

Rana, Purushottam S.J.B. 1998. Jung Bahadur Rana: the story of his rise and glory. Kathmandu: Book Faith India.

Ranabhumi (alias Deepak Rana) n.d. The bending reed. Kathmandu.

Rose, D. 1990. Living the ethnographic life. Newbury Park: Sage.

Schwerin, K. Gräfin 1993. Rana-Herrschaft und Paläste im Kathmandu-Tal 18461951. Saeculum 44: 243-64.

Sever, A. 1993. Nepal under the Ranas. Delhi: Oxford and IBH publisher.

Shore, C. \& S. Nugent (eds). 2002. Elite cultures: anthropological perspectives (ASA Monographs v.38. London: Routledge.

Sobral, J.M. 2000. Family, power and property: ascendancy and decline of a rural elite. In Elites: choice leadership and succession (eds) J. de Pina-Cabral \& A. Pedroso de Lima. Oxford: Berg. 
Spivak, G.C. 1988a. Can the subaltern speak? In Marxism and the interpretation of culture (eds) C. Nelson \& L. Grossberg, 271-313. Chicago: University of Illinois Press.

Spivak, G. C. 1988b. Practical politics of the open end. Canadian Journal of Political and Social Theory/Revue canadienne de théorie politique et sociale 12:104-11.

Thompson, J.J. 1997. Unmasking culture: women and beauty salons in Kathmandu Nepal. Unpublished PhD: University of Wisconsin-Madison.

von der Heide, S. 1997. Changing faces of Nepal: The glory of Asia's past. Kathmandu: Ratna Pustak Bhandar.

\section{About the author}

Stefanie Lotter is currently completing her $\mathrm{PhD}$ in Social Anthropology at the University of Heidelberg (Germany). She was posted in Kathmandu as the representative of the South Asia Institute of the Heidelberg University for two years (1998-1999) during which time she undertook fieldwork with a declining urban elite, the Rana. 